\title{
Sosa, Kiobel and Pirates Inc.: Defining the 'Modern' Parameters of the Archaic Alien Tort Statute
}

\author{
Jonathan LH Blaine ${ }^{*}$
}

\begin{abstract}
This article reviews and analyses the recent United States Supreme Court case of Kiobel v. Royal Dutch Petroleum Co. and its impact on over thirty years of jurisprudential development surrounding the role of United States ('US') federal courts in providing redress to victims of human rights violations occurring outside the US More specifically, this article recounts the case law setting forth the modern use of the over two hundred year old Alien Torts Statute ('ATS') as a means of expanding on developments in the field of international human rights. This modern interpretation argues that the jurisdiction of US federal courts, as set out in the ATS, can be broadly defined to include cases for tort claims arising in the context of violations of human rights where both the perpetrators and the acts concerned were outside the US This article then discusses how the US Supreme Court in the Kiobel decision not only closes off the use of the ATS in this context but so severely limits the jurisdiction provided under the ATS to its historical background as to make the jurisdiction provided thereunder almost meaningless under modern international law. This article also questions why the US Supreme Court went to extreme lengths to avoid addressing the original question raised in granting certiorari, namely, that of corporate liability under international law, and attempts to lay out the Court's possible rationales for doing so. The article then concludes with a discussion of potential ways forward in light of the Court's Kiobel decision.
\end{abstract}

\footnotetext{
* S.J.D. (Candidate), Australian National University College of Law; J.D. (cum laude) Seton Hall Law School; M.B.A. Chaminade University of Honolulu; B.A. Kent State University. The views expressed in this contribution are the author's alone and cannot in any way be attributed to the Australian National University. The usual disclaimer applies. The author can be contacted at: blainejo@gmail.com
} 
In April of 2013, the Supreme Court of the United States, in a highly contentious and procedurally unusual case, set back nearly thirty years of jurisprudential development in international human rights law ('IHRL') in the US when the Court decided in the case of Kiobel v. Royal Dutch Petroleum Co. ${ }^{1}$ to rein in the use of the Alien Tort Statute ('ATS') as a means of providing access to US federal courts for victims of human rights violations by defining its modern parameters. ${ }^{2}$ The ATS statute was enacted in 1789 to grant jurisdiction to US federal courts in cases involving torts committed in the context of international law violations. ${ }^{3}$ This statute laid almost completely dormant for almost two hundred years when in 1980 in the seminal case of Filartiga v. Pena-Irala ${ }^{4}$ the US Second Circuit Court of Appeals held that the statute's grant of jurisdiction was broadly worded enough to allow the US federal courts jurisdiction even in cases where the underlying acts had occurred outside the US In only its second case ever regarding the ATS, the Supreme Court in contradiction of Filartiga held that the ATS cannot be applied extraterritorially and, accordingly, does not grant US federal courts jurisdiction to hear claims under the for torts committed in violation of the law of nations where the tortious acts take place outside the US. ${ }^{5}$

The Kiobel holding not only calls into question several cases currently under consideration in lower federal courts but has broader implications for victims' access to courts of justice for restitution and compensation for torts suffered at the hands of human rights violators world-wide. This ruling effectively shuts off access to the US system for potentially thousands of victims around the world and sets back what had come to be seen as a viable avenue for the expansion of human rights protections; namely, access to

\footnotetext{
${ }^{1}$ Kiobel v. Royal Dutch Petroleum Co., 17 April 2013, US Supreme Court, 133 S. Ct., p. 1659.

${ }^{2} 28$ USC. $§ 1350$ (2006) (“The district courts shall have original jurisdiction of any civil action by an alien for a tort only, committed in violation of the law of nations or a treaty of the United States").

${ }^{3}$ Ibid.

${ }^{4}$ Filartiga v. Pena-Irala, 30 June 1980, US Court of Appeals for the Second Circuit, 630 F.2d., p. 876.

${ }^{5}$ Kiobel v. Royal Dutch Petroleum Co., supra note 1, p. 1669.
} 
redress for victims of tortious activity through municipal legal systems in the absence of an international system.

This essay will present a short history of the vague origins of the ATS and the reawakening of the statute as a 'modern' tool of IHRL under Filartiga after almost two hundred years of dormancy. Then attention will be given to the Supreme Court's first ever consideration of the ATS in the case of Sosa v. Alvarez-Machain and the Court's decision to pull back on the expansive application of the ATS and place limits on the types of cases falling within the prevue of courts thereunder. ${ }^{6}$ Next, consideration will be given to the Court's effective gutting of the 'modern' ATS in the Kiobel case by strictly limiting its reach to injuries suffered by aliens within the territorial limits of the US ${ }^{7}$ Finally, this essay will discuss one significant, pressing and still open issue: that of whether corporations can be held liable for "tort(s) . . committed in violation of the law of nations or a treaty of the United States" ${ }^{\prime 8}$ under the ATS, along with commentary as to why the Supreme Court appears to have gone out of its way to avoid this fairly significant issue and how it might rule when and if the issue comes to it again. But first, a short history lesson regarding the establishment of the US federal court system and the role of the first congress in defining federal jurisdiction of these courts under the US Constitution.

\section{The First Two Hundred Years}

When the US Constitution was ratified in 1788, it provided for the creation of certain federal courts, with specific provisions made for the Supreme Court's original jurisdiction in certain matters, and Congress's ability to create other 'inferior' courts and grant them jurisdiction. ${ }^{9}$ In satisfaction of its duties under the new Constitution, the first

\footnotetext{
${ }^{6}$ Sosa v. Alvarez-Machain, 29 June 2004, US Supreme Court, 542 US, p. 692.

${ }^{7}$ Kiobel v. Royal Dutch Petroleum Co., supra note 1, p. 1669.

828 United States Code $§ 1350$ (2006).

${ }^{9}$ US Constitution, art. III, $\S 1$ ("The judicial Power of the United States shall be vested in one supreme Court, and in such inferior Courts as the Congress may from time to time ordain and establish. The Judges, both of the supreme and inferior Courts, shall hold their Offices during good Behaviour, and shall, at stated
} 
Congress, which held session in 1789 , passed the Judiciary Act ${ }^{10}$ setting out the jurisdiction of several federal courts. Section 9 of this act, which came to be known as the ATS, read:

"[District courts] shall also have cognizance, concurrent with the courts of the several States, or the circuit courts, as the case may be, of all causes where an alien sues for a tort only in violation of the law of nations or a treaty of the United States."11

Thus, the provision was born and then fell into obscurity. ${ }^{12}$ Little is known about the actual intention of the drafters, as most of the legislative history providing the underlying motivations behind the incorporation of this provision in the Judiciary Act have been lost to time. Indeed, this statute was famously referred to by Judge Friendly as "a kind of legal Lohengrin [as] no one seems to know whence it came." 13

It is from these humble beginnings that the ATS very unexpectedly became after almost two hundred years of relative dormancy - the hope of many an individual victim of human rights abuses the world over In 1980, a US federal circuit court held in the pivotal case of Filartiga that the ATS' grant of jurisdiction to US federal courts in cases where torts are committed in violation of the law of nations was broad enough to include torts suffered by an alien at the hands of another alien, even if the acts took place outside the US. ${ }^{14}$

Filartiga involved a suit by a Paraguayan widow, Dolly Filartiga (Dolly), and her father in law, Dr. Joel Filartiga, for the torture and murder of her husband by Americo Norberto Pena-Irala (Pena), who at the time was the Inspector General of Police in the

Times, receive for their Services a Compensation, which shall not be diminished during their Continuance in Office").

${ }^{10}$ Judiciary Act, 1 Stat. p. 73 (1789).

${ }^{11}$ Judiciary Act of 1789, ch. 20, §9(b), I Stat. 73, 77.

${ }^{12}$ A search for cases via LexisNexis reveals that there have only been 12 federal cases mentioning the ATS, all of which are decided after 1980.

${ }^{13}$ IIT v. Vencap, Ltd., 28 April 1975, US Court of Appeals for the Second Circuit, 519 F.2d., p. 1015.

${ }^{14}$ Filartiga v. Pena-Irala, supra note 4, p. 885. 
city of Asuncion, Paraguay. ${ }^{15}$ As it happened, Dolly had sought asylum in the US and was residing in Washington D.C. when she learned that Pena was staying in New York. ${ }^{16}$ Dolly filed a claim against Pena in the Eastern District of New York asserting jurisdiction under the ATS for the wrongful death of her husband. ${ }^{17}$ The District Court dismissed the complaint on jurisdictional grounds, reading the language in the statute regarding 'the law of nations' narrowly, to mean exclusive of actions by a state involving its own citizens. $^{18}$

In a unanimous decision, the three judges of the $2^{\text {nd }}$ Circuit held that torture had become part of 'the law of nations', pointing to several sources including the United Nations Charter ${ }^{19}$, the United Nations Declaration of Human Rights ${ }^{20}$ and other general assembly resolutions. In reviewing these sources the judges were concerned mainly with making a determination as to whether torture had become part of customary international law. ${ }^{21}$ This was important in the US federal context because the courts had tended to take a cautious approach to the expansion of laws that fall within the definition of the law of nations', so as to prevent confusion among the states and to avoid "idiosyncratic legal rules" that might be developed by one state as a political tool against other states. ${ }^{22}$

They are also quite cognizant of the historically limited role of the courts in the area of foreign affairs and international relations. They believe they are on better footing when the other branches of government, the legislature and the executive, have provided guidance or developed norms in situations that clearly touch on international relations, such as international laws and rules which specifically address how parties acting

\footnotetext{
${ }^{15}$ Ibid,. pp. 878-879.

${ }^{16}$ Ibid.

${ }^{17}$ Ibid.

${ }^{18}$ Ibid., p. 880.

${ }^{19}$ United Nations, Charter of the United Nations, 24 October 1945, 1 UNTS XVI, available at: <www.un.org/en/documents/charter>, accessed 16 June 2014.

${ }^{20}$ United Nations, General Assembly, The Universal Declaration of Human Rights, 10 December 1948, 217 A (III), available at: <www.un.org/en/documents/udhr>, accessed 16 June 2014 (hereinafter,

Declaration of Human Rights).

${ }^{21}$ Filartiga v. Pena-Irala, supra note 4, p. 880.

${ }^{22}$ Ibid., p. 881.
} 
transnationally should behave. They appeared to believe that this requirement had been satisfied and that the other branches of government had spoken through treaty negotiation and ratification of the UN Charter and the US participation through the UN in the Declaration on Human Rights ${ }^{23}$, Declaration on the Protection of All Persons from Being Subjected to Torture and others. ${ }^{24}$. They "conclude[d] that official torture is prohibited by the law of nations" and that such actions are not permissible under international law whether committed by a state against aliens or, indeed, its own citizens. ${ }^{25}$

Having found that torture was now part of customary international law, and consequently part of US federal common law, the judges then turned to addressing whether the ATS was purely jurisdictional and merely opened the doors of the federal courts, or whether the ATS could actually be read as granting new rights (i.e., substantive rights) to aliens. ${ }^{26}$ The court opined that the statute should be read narrowly as a jurisdictional statute providing access to the courts for violations of 'recognised' international laws; the fear being that while courts in a common law system specifically define what the law is, in the case of the US federal system, there is very little room for federal common law, as such law historically derives from the police power of the state. As the US federal government is constituted by the individual states granting power to the federal government, it would seem quite antithetical to suggest that the federal government possesses an extensive common law of its own with no known origins: a different manifestation of the legal Lohengrin, one might say. This does not mean that federal common law does not exist, as it clearly does, and customary international law forms part of it, but it is a different point altogether to admit a power to judges under the

\footnotetext{
${ }^{23}$ Declaration of Human Rights, supra note 20.

${ }^{24}$ General Assembly resolution 30/3452, Declaration on the Protection of All Persons from Being Subjected to Torture and Other Cruel, Inhuman or Degrading Treatment or Punishment, A/RES/30/3452 (9 December 1975), available at: <www.un-documents.net/a30r3452.htm>, accessed 16 June 2014 (hereinafter Declaration on Torture)

${ }^{25}$ Filartiga v. Pena-Irala, supra note 4, p. 884.

${ }^{26}$ Ibid. p. 887.
} 
common law to simply create the 'law against nations', as they might do in the case of common law torts. ${ }^{27}$

The importance of the Filartiga case should not be underestimated. The case has been referred to as the "decision that launched modern human rights litigation" in the US, breathed new life into the ATS, and ushered in the 'modern' ATS and human rights era. ${ }^{28}$ Since the Second Circuit's ruling, several cases have been filed in the federal courts based on ATS jurisdiction and the courts at both the district and circuit levels have struggled to agree on the limits of modern ATS jurisdiction. Lurking behind the Filartiga case are numerous issues raised by use of the statute, such as those relating to the private law/public law divide, the tort/crime dichotomy, the municipal/cosmopolitan debate and the self-executing/non-self-executing distinction. ${ }^{29}$

These questions are raised to varying degrees by the Supreme Court in the only two cases it has ever heard regarding ATS: Sosa ${ }^{30}$ and Kiobel. ${ }^{31}$ Through these two extremely important cases, the Court first provides guidance as to how courts can determine which causes of action might come within the jurisdictional boundaries of the ATS, and then building on this taxonomy, the Court draws a definitive bright line rule clearly setting out the jurisdictional limits of the ATS for a particular set of causes. In doing so, the court quashed the hopes of many, who had seen the US approach to the vindication of human rights violations as a "unique phenomenon"32.

\footnotetext{
${ }^{27}$ For a critique of the 'modern position' that customary international law is part of federal common law, see generally, C. A. Bradley and J. L. Goldsmith, 'Customary International Law as Federal Common Law: A Critique of the Modern Position', 110 Harvard Law Review (1997) p. 815.

${ }^{28}$ C. M. Vázquez, 'Alien Tort Claims and the Status of Customary International Law', 106 The American Journal of International Law (2012) p. 531.

${ }^{29}$ See generally, C. Scott (ed.), Torture as Tort: Comparative Perspectives on the Development of Transnational Human Rights Litigation (Hart Publishing, Portland, Oregon, 2001).

${ }^{30}$ Sosa v. Alvarez-Machain, supra note 6.

${ }^{31}$ Kiobel v. Royal Dutch Petroleum Co., supra note 1.

${ }^{32}$ Ibid., p. 3.
} 
Both the Sosa and Kiobel cases are the first of their kind for the US Supreme Court. ${ }^{33}$ During the statute's entire two hundred year existence, no case regarding the application of the ATS had reached the Court. Even after the landscape altering circuit court decision in Filartiga in 1980, it was over twenty years before the US Supreme Court took up its first case regarding the application of the ATS. When the Court heard arguments in Sosa v. Alvarez-Machain ${ }^{34}$ it was the Court's first opportunity to weigh in on what had become one of the most discussed provisions of IHRL jurisprudence in the US. It was clear that the developments over the past twenty years and the use of ATS as a tool of the transnational human rights bar, at least in the US, needed some signal as to their validity. Congress had been silent on the expanding use of the ATS during this period so little official guidance had been provided either way. ${ }^{35}$ This led to a split among the circuits and the IHRL bar as to whether the ATS could be read in such a way as to provide victims of torture or other human rights atrocities the world over with a forum for redress. The Court took this opportunity to provide the much needed guidance, but in doing so, put a quick halt to the expansion and began the reversal of twenty years of IHRL jurisprudence in the US

\subsection{Sosa v. Alvarez-Machain}

Sosa involved the kidnapping of a Mexican national, Dr. Humberto Alvarez-Machain from Mexico and his transportation to the US to stand trial for torture and murder charges relating to his participation in the death of a DEA agent at the hands of drug cartel in Mexico. ${ }^{36}$ His complaint alleged that the individual DEA agents had arranged for Sosa, another Mexican national, to kidnap him in Mexico and spirit him across the US -

\footnotetext{
${ }^{33}$ Sosa v. Alvarez-Machain, supra note 6; Kiobel v. Royal Dutch Petroleum Co., supra note 1.

${ }^{34}$ Sosa v. Alvarez-Machain, supra note 6.

${ }^{35}$ While the government had been silent on the use of ATS for IHRL cases, the academy was certainly at no loss for opinions on the use of the ATS and its application. A simple search of US law reviews alone returned nearly 2,000 articles mentioning the ATS, with the vast majority being written after Filartiga was decided in 1980 .

${ }^{36}$ Sosa v. Alvarez-Machain, supra note 6, pp. 697-698.
} 
Mexico border. Alvarez-Machain sued both the DEA and Sosa, basing federal jurisdiction for the claim against Sosa under the ATS for a tortious violation of his rights under the law of nations based on arbitrary detention. ${ }^{37}$ Sosa claimed that the ATS could not serve as the basis for any tortious violation unless Congress specifically enacted legislation granting a right of action under the ATS. ${ }^{38}$ The Court took up the case to address these and other issues, and in its decision defined, for the first time, the jurisdictional parameters of the ATS.

When considering what types of claims might fall within the jurisdictional limits of the ATS the Court was presented with three alternative readings of the ATS.

The first was the 'originalist' position. This was build on the argument that the ATS was a purely jurisdictional statute providing the federal courts with the ability to hear only those limited cases involving violations of the law of nations at that time, such as violations of the right to safe-conduct, diplomatic law, and piracy. ${ }^{39}$ The second and opposing argument, which has come to be called the 'modern' position, encouraged a broad reading of the wording of the statute so as to include modern international human rights norms, such as torture, extrajudicial killing and genocide as falling within its grasp. The third position was a more nuanced position between these two polar opposites, and the position the Court ultimately settled upon, namely, that the statute was jurisdictional but as it includes causes of action under federal common law, which in turn include customary international law, as long as the cause of action can be found to be part of customary international law then such cases are actionable under the ATS.

The Court then set out the following parameter as to which private claims can be recognised under federal common law: only those claims that do not possess "less definite content and acceptance among civilized nations than the historical paradigms familiar when [the ATS] was enacted. ${ }^{, 40}$ In attempting to provide some clarification the Court quotes a lower court opinion stating that in order for such claims to be actionable under the ATS the must be international norms that are "specific, universal, and

\footnotetext{
${ }^{37}$ Ibid., p. 736.

${ }^{38}$ Ibid., p. 712.

${ }^{39}$ W. Blackstone, Commentaries on the Laws of England, Vol. 4 (1769), p. 68.

${ }^{40}$ Sosa v. Alvarez-Machain, supra note 6, p. 732.
} 
obligatory". ${ }^{41}$ In setting out this test the Court recognised that this left open the criterion upon which such norms can be adjudged, but believed that the norms must meet this jurisdictional limitation. ${ }^{42}$ Having set out the initial parameters as to the 'types' of actions which may be heard under the jurisdiction granted by the ATS, the Court then proceeded to analyse whether arbitrary arrest and detention fell within this category of cases. It found that they did not, on the basis that they were "far from full realization" 43 as international human rights norms and therefore not yet part of customary international law. ${ }^{44}$ By focusing on the nature of the violations and their acceptance as international norms, the court avoided one significant aspect of Filartiga that would eventually be taken up and prove critical in the Kiobel case; the question of whether the ATS had extraterritorial reach to cover actions by a tortfeasor occurring outside the territorial boundaries of the US.

Justice Breyer's concurring opinion in Sosa seemed to hint at this very concern when he discussed the universality of the ATS. ${ }^{45}$ In considering the Court's majority opinion, Breyer directed attention to universal jurisdiction and the applicability of such jurisdiction for private civil claims, pointing to near universal acceptance of claims for universal jurisdiction with regards to international criminal law. From this Breyer proposed that universal jurisdiction might also be available for certain civil actions, specifically those tied closely to recognised international crimes. ${ }^{46}$ Breyer concluded that the widespread acceptance of universal criminal jurisdiction supported universal civil jurisdiction in these limited contexts. ${ }^{47}$

He seems to have the better argument here. Given that the consequences inherent in State punishment for criminal actions are normally more severe and include significant state interference with personal liberties, such as imprisonment and capital punishment., it would seem that universal jurisdiction in the international criminal context is an

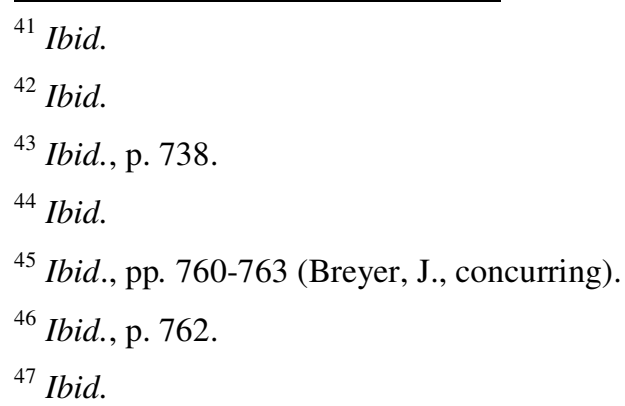


incredibly intrusive extension of State power into the sovereignty of other States. It gives foreign States the ability to impose punishment on other State's nationals, over whom these States have historically been granted complete control. Given the acceptance of the broad intrusiveness of State power in these contexts, it would seem a lesser issue where States are merely seeking to punish tortious behavior through the imposition of civil penalties (i.e., monetary damages) upon the nationals of another State. Whilst there is an argument to be made that the acts being addressed in the former are of greater portent and thus support the greater intrusion, Justice Breyer's argument that the acceptance of universal jurisdiction for criminal liability leads directly to the conclusion that such jurisdiction is supported in the civil context, at least where the acts are consistent with criminal acts of the same nature, is a strong one.

Yet in concluding that universal jurisdiction for civil liability should apply in the context of human rights violations, he then proceeded to question whether such jurisdiction would apply to the case at hand due to the "lack of [international] consensus supporting the exercise of jurisdiction for [arbitrary arrest and detention]" 48 and concluded that it would not. ${ }^{49}$ Thus the Court's failure to specifically address the extraterritorial application of the ATS led some commentators to conclude that the US Supreme Court's ruling in Sosa "had affirme[d] the Filartigai paradigm". ${ }^{50}$ However, this was not to prove so, when the Supreme Court took up its second ever ATS case, Kiobel $v$. Royal Dutch Petroleum Co. ${ }^{51}$

\subsection{Kiobel v. Royal Dutch Petroleum ${ }^{52}$}

Kiobel is an interesting case, not only for the eventual holding by the Supreme Court regarding the limitations of ATS jurisdictions and the myriad international law issues presented therein, at both the Circuit Court and Supreme Court levels, but also for its

\footnotetext{
${ }^{48}$ Ibid. p. 763.

${ }^{49}$ Ibid.

${ }^{50}$ N. Norberg, 'The US Supreme Court Affirms the Filartiga Paradigm', 4 Journal of International Criminal Justice (2006) pp. 387-400.

${ }^{51}$ Kiobel v. Royal Dutch Petroleum Co., supra note 1, p. 1659.

52 Ibid.
} 
highly unusual procedural history. ${ }^{53}$ It is one of the few instances where the Court asked not only for additional briefing on a separate issue from that raised in the initial appeal, but also held the case over from one term to the next in order to allow for sufficient briefing by amici, and to have a rehearing on the newly raised issue. The uniqueness of such actions would not be lost on any serious observer of the Court, as these actions point directly to the Court's desire to avoid having to decide the case based on the original issue under consideration: that of corporate liability under international law. This procedural background is so unusual that it deserves some specific consideration before turning to a fuller discussion of the facts and conclusions of the case.

The case originated as a claim in the Southern District of New York and proceeded as normal to the Second Circuit Court of Appeals, before making its first appearance for oral argument before the US Supreme Court. ${ }^{54}$ This first appearance at the Court was on appeal from the decision of the Second Circuit, holding that the case against Royal Dutch Shell should be dismissed on the grounds that corporations cannot be held liable for any actions under the "law of nations" as customary international law does not recognise corporate liability. ${ }^{55}$

This issue was front and center in the Second Circuit's opinion and, thus, when the Supreme Court took up the case it was specifically to address corporate liability for international human rights violations and the ability of US federal courts to entertain such actions under the ATS. ${ }^{56}$ But this is where the normal process took a quite unexpected turn. In a highly unusual procedural step, after hearing the first oral arguments, the Court issued an order requesting subsequent full briefing on the issue of extraterritorial application of the ATS and held the case over from the 2012 session to the 2013 session, scheduling oral argument for October 2012. ${ }^{57}$ The original oral argument had been in February of 2012. It is highly unusual for the Court to proceed the entire way through a case and then ask for briefing on entirely different grounds than those presented as the

\footnotetext{
${ }^{53}$ Ibid., p. 1663.

${ }^{54}$ Ibid..

${ }^{55}$ Ibid.

${ }^{56}$ Ibid.

${ }^{57}$ Ibid.
} 
basis for the lower court's decision. However, it had occurred in the not too distant past, so there was some precedent to follow. ${ }^{58}$

It was though this unusual route that the Court found itself able to dispense with the case on the grounds that the ATS does not have extraterritorial application, thereby avoiding the corporate liability issue altogether and effectively slamming the door on that portion of the modern use of ATS that had allowed for cases by aliens against aliens for acts committed outside the US Given this dramatic altering of more than twenty years of expansive jurisprudential development, the Court's logic, motivations and reasoning deserve retelling and analysis here. This analysis will be followed by a discussion of the unaddressed and unresolved issue of corporate liability under customary international law. But first, the facts of the case.

\subsubsection{District Court Opinion}

A group of Nigerian nationals who had lived in Nigeria, but were at the time of the suit living in the US, brought a class action law suit against Dutch, British and Nigerian oil companies conducting oil exploration and production activities in Nigeria. ${ }^{59}$ The plaintiff class accused these corporations of aiding and abetting torture along with the Nigerian government. ${ }^{60}$ The accusations against the corporate agents were that they sought help from the Nigerian government "to violently suppress the burgeoning demonstrations" ${ }^{61}$ involving residents who had started protesting against the activities of the corporations. ${ }^{62}$ The protestors, who were local residents, believed that these companies were destroying the environment and as such began to disrupt exploration and production activities. ${ }^{63}$ The corporations appealed to the government for assistance. ${ }^{64}$ The government obliged by

\footnotetext{
${ }^{58}$ See generally, Citizens United v. Federal Election Commission, 21 January 2010, US Supreme Court, 558 US, p. 310.

${ }^{59}$ Kiobel v. Royal Dutch Petroleum Co., supra note 1, p. 1662.

${ }^{60}$ Ibid.

${ }^{61}$ Ibid.

${ }^{62}$ Ibid.

${ }^{63} \mathrm{Ibid}$.

${ }^{64}$ Ibid.
} 
sending in military and police forces to violently suppress the protests. ${ }^{65}$ The allegations were that government actors beat, raped, killed and arrested residents as well as looted and destroyed property. ${ }^{66}$ The corporations were also accused of aiding and abetting these activities by providing food, transportation, compensation and use of their property. ${ }^{67}$

The plaintiffs brought their action once they had relocated to the US after having sought asylum there. ${ }^{68}$ The complaint at the District Court asserted numerous claims including 1) extrajudicial killings, 2) violations of the right to life, liberty, security, and association, 3) forced exile, 4) property destruction, 5) crimes against humanity, 6) torture, and 7) arbitrary arrest and detention. More specifically, the claims directed at the corporations related to aiding and abetting these violations. ${ }^{69}$ The plaintiffs asserted jurisdiction under the ATS for all these claims ${ }^{70}$ and as such the District Court addressed each of these in the context of ruling on a motion to dismiss, to determine if they could be properly heard in US federal courts under that provision, especially in light of the decision in Sosa. ${ }^{71}$

As the issue of aiding and abetting was central to the claims, the court first turned to the question of whether "private individuals can be held liable under the ATS for aiding and abetting violations of international law."72 They recognised that prior to Sosa, suits based on secondary liability had previously been permitted in the Second Circuit and thought it "a close question". ${ }^{73}$ Even so, the court held that if a claim could be viable under the ATS, then aiding and abetting such a claim could also. ${ }^{74}$

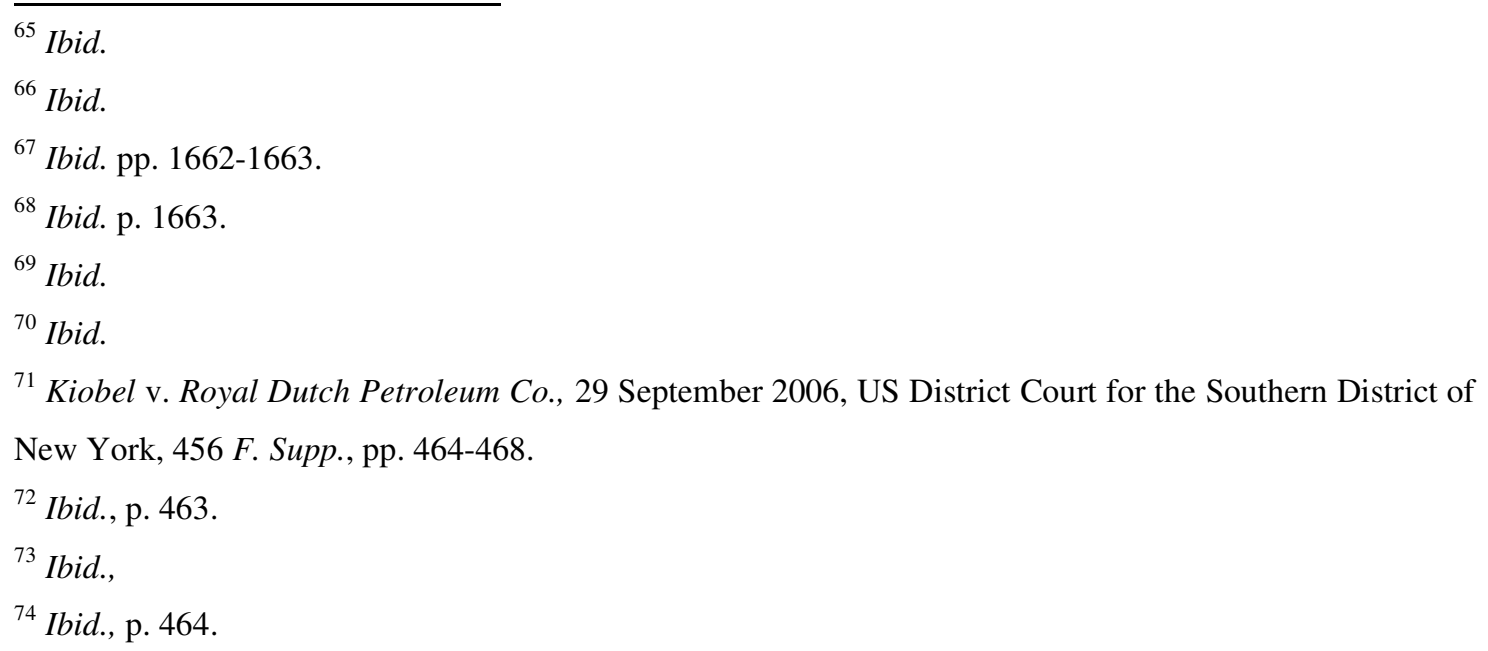


As regards extrajudicial killings, the judge relied on Sosa in analysing whether killings carried out not by courts but by a special tribunal established pursuant to an exercise of State power might be considered extrajudicial, especially in light of the corrupt nature of some such tribunals, where intimidation of witnesses and counsel, witness tampering and bribery were involved. ${ }^{75}$ The court held that killings under such circumstances had not been recognised customarily as a form of extrajudicial killing. ${ }^{76}$ While the judge did cite Sosa for the proposition that some forms of judicial killing may be recognised as violations of the law of nations, killings in this context had not been the subject of a well-defined custom against such actions under international law. ${ }^{77}$

The claims concerning the violation of the right to life, liberty, security, and association were then discussed. ${ }^{78}$ The Plaintiffs' claims were that the actions of the military and police in putting down peaceful demonstrations were a violation of political and civil rights, and that the murdering of certain protest leaders was also a violation of their rights. ${ }^{79}$ The defendant oil companies argued that there was no generally accepted, or universal understanding of civil or political rights and thus, following the decision in Sosa that prohibited courts from recognising private rights of action that have "less definite content and acceptance among civilized nations than the historical paradigms familiar when [the ATS] was enacted" ${ }^{\prime \prime}$, these claims were not actionable. The court agreed with this analysis and dismissed the claims accordingly. ${ }^{81}$

The Plaintiffs' claims that forced exile could be grounds for an ATS cause of action were also considered. ${ }^{82}$ The court found that there had never been a case permitting a claim of forced exile under the ATS. ${ }^{83}$ The court then again cited Sosa and

\footnotetext{
${ }^{75}$ Ibid., pp. 464-465.

${ }^{76}$ Ibid., p. 465.

${ }^{77}$ Ibid.

${ }^{78}$ Ibid., p. 467.

${ }^{79}$ Ibid.

${ }^{80}$ Ibid.

${ }^{81}$ Ibid.

${ }^{82}$ Ibid. p. 464.

${ }^{83}$ Ibid.
} 
the limitations thereunder in holding that forced exile cannot serve as an actionable claim under the ATS. ${ }^{84}$

The court then focused on the claims that property destruction should be actionable under ATS as tort in violation of the law of nations. ${ }^{85}$ The Plaintiffs claimed that property confiscation and destruction was "directed at a distinct ethnic group" was therefore discriminatory. However, they did not allege that such acts were committed as part of a genocide, or as war crimes. ${ }^{87}$ The court agreed that if property damage was performed in the context of genocide or alongside other war crimes, then it would be actionable in tort. ${ }^{88}$ In the absence of such claims, however, property destruction was not a tort committed in violation of the law of nations, and subsequently, not actionable under the ATS. ${ }^{89}$

In addressing whether crimes against humanity can be actionable the court had no problem in finding that such acts easily fall within the ATS. ${ }^{90}$ Defendants had claimed that the category of 'crimes against humanity' was vague and comprised a catch-all category, and as such, would not possess of a definite content as required by Sosa. ${ }^{91}$ The court disagreed with defendants assertion and held that as long as the complained of acts of rape and torture fell within the Rome Statute's definition of crimes against humanity, then damages suffered from those actions were redressable torts under the ATS. ${ }^{92}$

\footnotetext{
${ }^{84}$ Ibid.

${ }^{85}$ Ibid.

${ }^{86}$ Ibid.

${ }^{87}$ Ibid.

${ }^{88}$ Ibid.

${ }^{89}$ Ibid.

${ }^{90}$ Ibid.

${ }^{91}$ Ibid., p. 467.

${ }^{92}$ Ibid. The reference to the Rome Statute is an interesting one in that the US, while a signatory to the Rome Statute has not ratified the treaty and is therefore not a States Party. The court here does however rely on the statute as an indication of the acceptance of crimes against humanity as customary common law and for the definition contained therein to show definiteness, as required under Sosa. In so holding, the court has effectively opened the door to US courts for parties suffering from crimes against humanity. It is noted however, that this opinion is the lower court opinion and precedes the Supreme Court's later ruling on the territorial nature of the ATS, effectively shutting the door opened here.
} 
As regards the claims of torture and inhumane treatment, the court stated that it appears unclear under Sosa "what conduct is included within "torture", but noted that it appeared to allow enough room for some forms of torture to be actionable under the ATS. ${ }^{93}$ This analysis of claims of torture appears a bit inconsistent with the court's analysis of crimes against humanity. Under those claims the judge made reference to the Rome Statute (to which the US is a signatory but not yet a State Party) and the definitions contained therein, yet in this instance no mention was made of the existence of the Convention Against Torture and Other Cruel, Inhuman or Degrading Treatment or Punishment ${ }^{94}$ and the definitions contained thereunder. ${ }^{95}$ Nor does the judge make reference to the Torture Victims Protection Act, ${ }^{96}$ which was enacted in 1991 pursuant to obligations under the Convention Against Torture, other than to say in a footnote that defendant's claims that the TVPA preempts claims for torture under the ATS had been rejected in a previous case and remained so in this case. ${ }^{97}$

The final claim that arbitrary arrest and detention should be actionable under the ATS strikes right at the heart of Sosa. ${ }^{98}$ In the Sosa case, the Supreme Court held specifically that arbitrary arrest and detention were not actionable under the ATS but limited its application to the facts of the case (i.e., detention of less than one day and for purposes or rendering someone to proper authorities for trial on a warrant). ${ }^{99}$ The district court judge in this case seized upon the factual limitations set out in Sosa and allowed the claims for arbitrary arrest and detention to proceed as they may have been actionable

\footnotetext{
${ }^{93}$ Ibid. p. 465, citing, Sosa v. Alvarez-Machain, supra note 6, pp. 736-737.

${ }^{94}$ Convention Against Torture and Other Cruel, Inhuman or Degrading Treatment or Punishment, Dec. 10, 1984, 1465 U.N.T.S. 85 (entered into force June 26, 1987) (hereinafter Convention Against Torture), <www1.umn.edu/humanrts/instree/h2catoc.htm> visited on 8 April 2014.

${ }^{95}$ Since the War in Iraq revealed troubling practices by the US military, such as waterboarding, there has been significant debate in the United States regarding what actually constitutes torture and what does not. For a full discussion of the debate, see generally, D. Weissbrodt \& C. Heilman, 'Defining Torture and Cruel, Inhuman, and Degrading Treatment', 29 Law \& Inequality (2011) p. 343.

${ }^{96} 106$ Stat. 73 (1991).

${ }^{97}$ Kiobel v. Royal Dutch Petroleum Co., supra note 58, p. 465 footnote 10.

${ }^{98}$ Ibid., pp. 465-466.

${ }^{99}$ Ibid., p. 466, discussing the Court's holding in Sosa v. Alvarez-Machain, supra note 85, p. 738.
} 
under the ATS where such detention "[was] both prolonged and a result of state policy" ${ }^{\prime 100}$.

Having provided its rulings on the ability of each of the claims to move forward, the court then granted an interlocutory appeal for a determination as to whether the counts of the complaint that were not dismissed are indeed actionable under the ATS. ${ }^{101}$ The defendants filed an appeal with the Second Circuit Court of Appeals. ${ }^{102}$ The Second Circuit Court heard arguments in the case in January 2009 and issued its ruling in the case in September 2010. ${ }^{103}$

\subsubsection{Second Circuit Opinion}

The Second Circuit Court of Appeal took up the case from the district court and, surprisingly, did not focus any of the issues raised in the lower court's opinion. ${ }^{104}$ There was no discussions of whether torture or crimes against humanity came under the newly curtailed ATS. The court entertained no arguments as to whether political or civil rights were sufficiently defined as to be recognised as customary international law. The court did not even address whether the lower court was right in its interpretation of the Supreme Court's holding in Sosa that prolonged state sponsored detention is still actionable under a post-Sosa ATS. Instead the Second Circuit Court dismissed the complaint entirely on the grounds that corporations could not be held liable for violations of customary international law. ${ }^{105}$

Never before had the Second Circuit Court held that corporations could not be liable for human rights abuses and it specifically noted so. ${ }^{106}$ The court did seek to emphasise that this issue had been "lurking for some time" 107 in the Second Circuit's

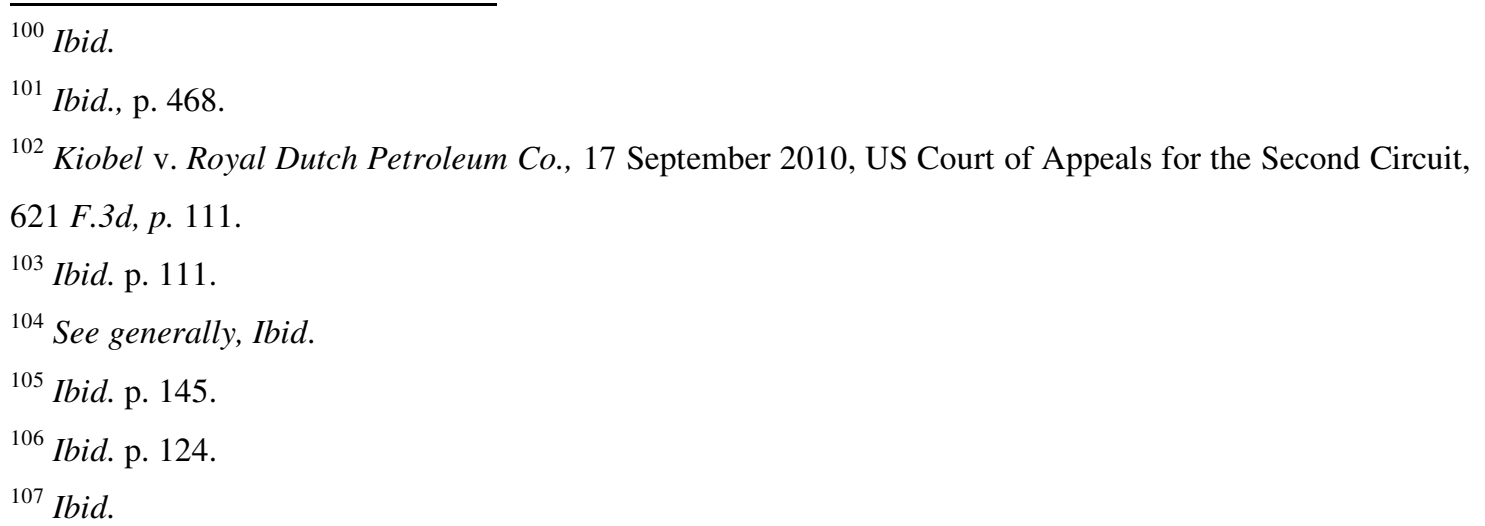


ATS jurisprudence but, notably, when listing the cases where the issue may have been relevant, the court was able to point to only two fairly recent instances - one in 2009 and the other in $2007 .{ }^{108}$ In one, the Second Circuit Court had "assumed without concluding" that corporations could be held liable under customary international law. ${ }^{109}$ In the other, the court did not address the issue because it was not raised at the lower court as noted only in a concurring opinion. ${ }^{110}$ The court then proceeded to point out that the same judge also stated that corporations could not be liable under the ATS in a separate concurring and dissenting opinion in the same case. ${ }^{111}$ Contrary to the Second Circuit's assertion that this issue was 'lurking', it seems more like the court went hunting for the issue. Nevertheless, it was this unprecedented and controversial issue, namely, that corporations could not be held liable for violations of customary international law, upon which the court relied in dismissing the appeal and with it all of plaintiff's causes of action. ${ }^{112}$

In reaching this precedent setting conclusion the court relied on a two pronged analysis. ${ }^{113}$ First, the court addressed the perpetual issue of which law, either municipal or international, should govern the analysis at hand. ${ }^{114}$ In analysing which law should apply the court focused on the nature and purpose of the ATS and noted that the ATS was specifically targeted at the law of nations and customary international law. ${ }^{115}$ As such, it was to this law the court choose to defer in making a determination as to whether customary international law makes any mention at all of corporations. ${ }^{116}$ Second, the court concluded that customary international law, especially those laws existing at the time of the passage of the ATS, focused solely on the culpability of individuals. The

${ }^{108}$ Ibid.

${ }^{109}$ Ibid., citing Presbyterian Church of Sudan v. Talisman Energy, Inc., 2 October 2009, US Court of Appeals for the Second Circuit, 582 F.3d, p. 261.

${ }^{110}$ Kiobel v. Royal Dutch Petroleum Co., supra note 103, p. 124, citing Khulumani v. Barclay National Bank Limited, 12 October 2007, US Court of Appeals for the Second Circuit, 504 F.3d, pp. 282-283.

${ }^{111}$ Kiobel v. Royal Dutch Petroleum Co., supra note 103, p. 124.

112 Ibid., p. 145.

113 Ibid., p. 125.

${ }^{114}$ Ibid.

115 Ibid., p. 126.

${ }^{116}$ Ibid., p. 131. 
court proceeded with a recitation of the various sources of customary international law, and dismissed the idea that any of them envisages corporate liability. ${ }^{117}$

Underlying this second conclusion was the court's extensive review of the history of international tribunals, from Nuremburg to the International Tribunal for the Former Yugoslavia and to the Rome Statute. It noted that the focus of each was that of liability for individuals, and specifically not that of collective punishment. ${ }^{118}$ After this survey revealed that not one single corporation had been the subject of a war crimes trial, the court concluded that it was "abundantly clear that, since Nuremberg, the concept of corporate liability for violations of customary international law has not yet begun to "ripen' into a universally accepted norm of international law." ${ }^{119}$ From here the court conducted an arguably incomplete analysis of another important source of customary international law; that of treaties. ${ }^{120}$

When assessing the role of treaties in establishing a custom of corporate liability under international law (i.e., effectively equating them to persons), the court sought to limit the impact treaties can have in establishing customary international law in the first instance by stating that treaties merely provide some evidence of the custom and practice of nations. ${ }^{121}$ They noted that even though a handful of treaties addressed corporate liability, these treaties did so in a different context from human rights and as such, did not present a sufficient basis for claiming that corporate liability had become a norm of IHRL. ${ }^{122}$

Contrary to the Second Circuit Court's assertion here, there is one fairly large set of treaties conspicuously absent from their analysis: international tax treaties. There are literally hundreds of bilateral international conventions on double taxation that have been signed and ratified by numerous countries around the world. The US alone has signed

\footnotetext{
${ }^{117}$ Ibid., pp. 131-145.

${ }^{118}$ Ibid., pp. 132-137. For a fuller discussion of the individual v. collective punishment aspects of international criminal law, see generally, G. Simpson, Law, War and Crime: War Crimes Trials and the Reinvention of International Law (Polity Press, Cambridge UK, 2007), p. 69.

${ }^{119}$ Kiobel v. Royal Dutch Petroleum Co., supra note 103, p. 137.

${ }^{120}$ Ibid. pp. 137-139.

${ }^{121} \mathrm{Ibid}$

${ }^{122}$ Ibid., p. 141.
} 
and ratified well over 60 such treaties, as have most other developed and several developing countries. These treaties all, without fail, define corporations as 'persons'. ${ }^{23}$ Whilst admittedly, this definition is in the context of taxation, when considered along with the domestic origins of the corporation as a person under domestic law ${ }^{124}$ and considering that this has been the status of corporations under such treaties for over fifty years, and under the domestic laws of several nations for well over one hundred years, it is hard to see how the court could so easily push aside what it calls "a legal culture long accustomed to imposing liability on corporations" as completely meaningless in the international context. ${ }^{125}$

The hundreds of international treaties and the general impression they have created would seem to argue that the conception of corporations as juridical persons is nearly universal, and their involvement on an international scale is a strong argument against this court's dismissive conclusion that they are not recognised under international law. The apparent absurdity of this assertion, as pointed out by Judge Leval's concurring opinion, may be one reason why the Supreme Court decided against addressing this issue upon appeal. ${ }^{126}$

The final source discussed in the majority opinion were the works of publicists. ${ }^{127}$ Whilst the court again ddi not find such sources persuasive, it did look to them as "evidence of what the law really is." ${ }^{128}$ From the scant and summary discussion given

${ }^{123}$ See Convention between the Government of the United States of America and the Government of the United Kingdom of Great Britain and Northern Ireland for the Avoidance of Double Taxation and the Prevention of Fiscal Evasion with Respect to Taxes on Income and on Capital Gains [US-UK DTA] which reads "the term 'person' includes ... a company" (DTA art 3, cl. 1.a).

${ }^{124}$ See, Kiobel v. Royal Dutch Petroleum Co., supra note 103, pp. 117-118.

125 Ibid., p. 141.

${ }^{126}$ See, Ibid., pp. 152-153 (Leval, J., concurring). The Supreme Court recently addressed the issue of personhood status for corporations in the somewhat infamous US case of Citizens United v. Federal Election Commission, supra note 46, p. 343. In that opinion the majority found that associations of persons in the form of a corporation did not impact the rights of individuals to free speech, effectively finding that the corporation, as a mere aggregation of personal interests carries with it the same rights as the individuals that comprise the substance of the association.

${ }^{127}$ Kiobel v. Royal Dutch Petroleum Co., supra note 103, p. 142.

${ }^{128}$ Ibid., citing Sosa v. Alvarez-Machain, supra note 6, p. 734 (internal quotations omitted). 
these sources in the opinion, it is clear that the court placed little value on them. Thus, after selecting only a few commentators that supported the court's position, they closed the discussion with a rebuke of Judge Leval's stinging concurrence. ${ }^{129}$ Having found that that corporations were not the subjects of IHRL, either customarily or under any other source, the court held that corporations were not subject to suit under the ATS. ${ }^{130}$

The court reiterated that it simply could not find any substantial basis for concluding that corporations were subject to either International Criminal Law ('ICL') or civil liability under customary international law. ${ }^{131}$ In doing so, the court called into question the utilisation of the ATS, a simple jurisdictional statute having limited historical application, as a means of expanding upon the IHRL project by morphing the cosmopolitan, individualised, criminal liability claims recognised under ICL postNuremburg into a metropolitan, collective, civil liability claim under the ATS. Whilst the language of the ATS itself, with its references to tort and the law of nations, seems to invite such treatment, the court apparently thought that the project was going too far and decided to draw the line at the point of adding collective (i.e., corporate) punishment to the ever expanding list of ATS cases.

One need not imagine the significant amount of debate that occupied the space between the Second Circuit Court's controversial ruling and the Supreme Court's rehearing on completely separate grounds, as a great number of articles were written on the subject as well as at least one book. ${ }^{132}$ In fact, one prominent US law school dedicated an entire symposium to the issue along with a corresponding edition of the school's international law journal. ${ }^{133}$

\footnotetext{
${ }^{129}$ Kiobel v. Royal Dutch Petroleum Co., supra note 103, pp. 145-147.

${ }^{130}$ Ibid., p. 148.

${ }^{131}$ Ibid.

${ }^{132}$ M. Koebele, Corporate Responsibility Under the Alien Tort Statute: Enforcement of International Law Through US Torts Law (Koninklijke Brill NV, Leiden The Netherlands, 2009).

${ }^{133}$ Symposium: 'Corporate Responsibility and the Alien Tort Statute', 43 Georgetown Journal of International Law (2012) p. 989. Additional symposium materials available at <apps.law.georgetown.edu/continuing-legal-education/showEventDetail.cfm?ID=277> visited on 28 May 2014.
} 
The views expressed during this symposium varied widely. On the other side of the debate were those in support of corporations, many of whom had been struggling to find their way through the thicket of IHRL and some of whom found themselves the subject of ATS suits which proved costly to settle and even costlier to litigate. ${ }^{134}$ One somewhat prescient commentator specifically addressed the extraterritoriality issue that would eventually end the query into corporate liability, ${ }^{135}$ with another calling for amendment of the ATS to bring it into the modern age. ${ }^{136}$

Of all the comments, the one that may hold the most promise is the suggestion by one commentator calling for an international convention to define the limits of corporate liability. ${ }^{137}$ Such a convention would be consistent with the modern approach for dealing with such large international issues, specifically in the context of ICL. Relying on this model may prove a challenge, if the experiences of the Convention Against Torture ${ }^{138}$ or the Genocide Convention ${ }^{139}$ are anything to go by. Nevertheless, the advances these two conventions have made to the IHRL project appear to have been well worth the time and

\footnotetext{
${ }^{134}$ W. A. Reinsch, 'Economic implications of the Alien Tort Statute', 43 Georgetown Journal of International Law (2012) p. 1027. The issue of costly corporate litigation was of particular concern to the Circuit Court which mentioned that due to "the fact that many juries hearing ATS claims are capable of awarding multimillion-dollar verdicts [combined with the complexity and uncertainty around the law] ha[ve] led many defendants to settle ATS claims prior to trial.” Kiobel, 621 F.3d at 116.

${ }^{135}$ N. Erb \& O. Pell, 'Kiobel's New Focus on Extraterritoriality under the Alien Tort Statute Could put Resolution of the Corporate Liability Issue Indefinitely out of Reach', 43 Georgetown Journal of International Law (2012) p. 1073.

${ }^{136}$ K. Sjovoll, 'If the Shoe Does not Fit: Why the ATS Does not Work', 43 Georgetown Journal of International Law (2012) p. 1085.

${ }^{137}$ G. C. Hufbauer, 'Why Shouldn Shouldnhouldnational LawS Does not Work', 43 Georgetown Journal of International Law (2012) p. 1011.

${ }^{138}$ Convention against Torture and Other Cruel, Inhumane or Degrading Treatment or Punishment, New York, 10 December 1984, United Nations Treaty Series, vol. 1465, No. 24841, available at: $<$ www.ohchr.org/EN/ProfessionalInterest/Pages/CAT.aspx>, visited on 22 June 2014 (hereinafter Convention on Torture).

${ }^{139}$ Convention on the Prevention and Punishment of the Crime of Genocide, Paris, 9 December 1948, United Nations Treaty Series, vol. 78, No. 1021, available at: <www.ohchr.org/EN/ProfessionalInterest/Pages/CAT.aspx>, visited on 22 June 2014 (hereinafter Convention on Genocide).
} 
effort it took to have them negotiated, signed, ratified and implemented. While there are still examples of abuses of power and torture taking place throughout the world, it is commonly understood that these acts are not acceptable, and they are met with immediate international condemnation, if not action. This option may be the best hope for settling the issue of corporate liability under international law and provide much needed guidance as to how, when, where and by whom corporations that violate IHRL can be held accountable for their actions.

\subsubsection{Supreme Court Opinion}

When the US Supreme Court initially agreed to review the case, it was specifically to review the issue of corporate liability under the ATS. However, once the Court was called to order for oral argument, it didn't take long for the Court to reveal a preference to steer clear of the corporate liability issue, and a distinct preference to argue the as yet unbriefed issue of the extraterritorial nature of ATS jurisdiction. This was evident from the very first question posed by Justice Kennedy at oral arguments: "But, counsel, for me, the case turns in large part on this ... No other nation in the world permits its court to exercise universal civil jurisdiction over alleged extraterritorial human rights abuses to which the nation has no connection." ${ }^{140}$ And it continued from there, with the next three justices, Justice Ginsberg, ${ }^{141}$ Justice Alito, ${ }^{142}$ and Chief Justice Roberts ${ }^{143}$ all throwing up the extraterritorial question and throwing counsel through a loop. All the while, counsel on behalf of Kiobel tried, to no avail, to steer the court back to the corporate liability issue, even at one point suggesting that if the Court would like to address the extraterritoriality issue it might consider asking for a full briefing on the subject. ${ }^{144}$ Counsel further noted that the issue had been "raised by . . . respondents" amici largely . . . [and that] others that would be interested in this question have not been able to put the

\footnotetext{
${ }^{140}$ Transcript of Oral Argument 3, Kiobel v. Royal Dutch Petroleum Co., 133 S. Ct. 1659, (2012) No. 101491(Hereinafter Kiobel I) (quoting Amicus Brief for Chevron) (emphasis added).

${ }^{141}$ Ibid., p. 6.

${ }^{142}$ Ibid., p. 7.

${ }^{143}$ Ibid., p. 9 .

${ }^{144}$ Ibid. p. 8.
} 
other side before the Court." 145 Yet, the Justices persisted on maintaining the focus for the most part on the extraterritorial question.

Interspersed throughout the Court's extraterritorial inquiries, the Justices grappled with most of the major issues plaguing modern ICL and IHRL jurisprudence: issues such as universal jurisdiction, ${ }^{146}$ collective versus individual liability, ${ }^{147}$ source of law rules and choice of forum issues, ${ }^{148}$ torts versus crimes, ${ }^{149}$ providing refuge to international law violators, ${ }^{150}$ forum non conveniens, ${ }^{151}$ and sovereign immunity. ${ }^{152}$

In discussing the corporate liability issue, Justice Breyer made what has quickly become the most memorable comment of the oral argument. In an attempt to clarify the issue at hand the Justice drew attention to the lower court's creation of the "categorical rule [that one can] never sue a corporation" for international law violations. ${ }^{153}$ In retort to this proposition he presented the rather effective counterexample of "Pirates, Incorporated", ${ }^{154}$ his point obviously being that if individuals could be held accountable for piracy whereas corporations could not, then simply by incorporating, pirates could effectively escape liability. ${ }^{155}$ This argument seemed to close the door on the question of corporate liability as the basis for dismissing the cause of action under the ATS.

Within a week of these initial oral arguments in February, the Court took the surprising step of restoring this case to the calendar for re-argument and calling for additional briefing on the issue of "[w]hether and under what circumstances the [ATS] allows courts to recognize a cause of action for violations of the law of nations occurring

\footnotetext{
${ }^{145}$ Ibid. p. 11.

${ }^{146}$ Ibid. p. 3.

${ }^{147}$ Ibid. p. 5.

${ }^{148}$ Ibid. p. 6.

${ }^{149}$ Ibid.

${ }^{150}$ Ibid. p. 13.

${ }^{151}$ Ibid. p. 14.

${ }^{152}$ Ibid. p. 17.

${ }^{153}$ Ibid. p. 23.

${ }^{154}$ Ibid. p. 24.

${ }^{155}$ Ibid. p. 25.
} 
within the territory of a sovereign other than the United States." 156 The Court heard rearguments in October of that same year and issued an opinion in April of this year. In its final opinion the Court held that the ATS did not apply to conduct that occurred outside the U.S. ${ }^{157}$ While the Court was unanimous in its holding, the Justices disagreed as to how narrow the jurisdiction of the ATS should be drawn.

The Justices broke down into four camps. The majority opinion penned by Chief Justice Roberts held the presumption of extraterritoriality as being the determinative factor that would bar any and all claims for relief where the actions occured outside the US, and would allow only cases where the claims "touch and concern the territory of the US ... with sufficient force to displace the presumption against extraterritorial application." ${ }^{158}$ In a concurring opinion, Justice Kennedy seemed concerned that the test set out by the majority was too broad and might potentially foreclose some cases that should fall within the jurisdiction of the ATS. His opinion mentioned the passage of the TVPA and the distinct provision of that act. ${ }^{159} \mathrm{He}$ mentions this to support his opinion that a hard and fast rule against all extraterritorial application may not be appropriate as the nature of the particular claims should be analysed, as should the particular relationship of the presumption against extraterritorial application. ${ }^{160}$

In a second concurrence, Justice Alito thought the extraterritoriality test to be too narrow and argued for a broader test that would exclude not only claims where the activities occurred outside the US but also those based on actions inside the US, unless such "conduct is sufficient to violate an international law norm that suffices Sosa's requirements of definiteness and acceptance among civilized nations." ${ }^{161}$ In his opinion the only claims that might be actionable are those that relate specifically to the types of cases that were actionable when the ATS was enacted, and apparently very few other cases. The third and final concurring opinion, which was joined by three other Justices,

\footnotetext{
${ }^{156}$ Kiobel v. Royal Dutch Petroleum Co., 5 March 2012, US Supreme Court, 132 S. Ct., p. 1738.

${ }^{157}$ Kiobel v. Royal Dutch Petroleum Co., supra note 1, p. 1669.

${ }^{158}$ Ibid.

159 Torture Victim Protection Act, Pub. Law 102-256, 106 Stat. 73 (1991), available online at: http://www.gpo.gov/fdsys/pkg/STATUTE-106/pdf/STATUTE-106-Pg73.pdf

${ }^{160}$ Kiobel v. Royal Dutch Petroleum Co., supra note 1, p. 1669 (Kennedy, J., concurring).

${ }^{161}$ Ibid. p. 1670
} 
argued for a completely different basis for determining which cases fell within the jurisdiction granted under the ATS. ${ }^{162}$ This group of Justices called into question extraterritoriality as the appropriate test. ${ }^{163}$ Their argument was that the ATS was originally enacted with international considerations at its heart and focused specifically on the international crime of piracy as the example of extraterritorial application of the ATS. ${ }^{164}$ Their analysis revealed that piracy is actually considered to occur on the territory of the country whose flag the ship is flying and as such, is inherently a crime committed on the territory of another sovereign. ${ }^{165}$ The implication of this was that applying extraterritoriality as a test against modern day pirates, today's hostis humani generis modern human rights violators - was inconsistent with the intent behind the ATS and would leave open the door for the US to become a safe haven for international criminals who commit their terrible crimes abroad and then seek shelter inside the US. ${ }^{166}$ This argument appears to be the most consistent with recent movements toward addressing IHRL violations. As seen in the relevant provisions of the Convention on Torture ${ }^{167}$ and the Genocide Convention ${ }^{168}$, there is a movement to provide for expansive jurisdiction in such cases, including universal jurisdiction. Given this movement, Breyer's concurrence most fully embodies these modern conceptions of liability and his formulation allows for development of the jurisprudence with continued focus on limiting the project to its international moorings.

\section{Conclusion}

As interesting as the Supreme Court's judgment that the ATS does not apply to actions outside the US may be, it still leaves open the question of corporate liability under the ATS, and under customary international law more broadly. In ruling on the extraterritoriality issue the Court was able to dismiss the entire case without having to

\footnotetext{
${ }^{162}$ Ibid., pp. 1670-1678 (Breyer, J., concurring).

${ }^{163}$ Ibid. p. 1671.

${ }^{164}$ Ibid.

${ }^{165}$ Ibid. p. 1672.

${ }^{166}$ Ibid. p. 691.

${ }^{167}$ Convention on Torture, supra note 139.

${ }^{168}$ Convention on Genocide, supra note 140.
} 
address the corporate liability question. Kiobel leaves open this hotly debated issue, yet closes off access to the US federal courts to those who suffer at the hands of human rights violators. The Court's rationale for doing so is based on its determination that the issues are so vast and varied, and the potential for interference with international affairs so great, that it should not be up to the judiciary to set the parameters of modern human rights litigation; Congress would be the better venue for driving this project forward. Congress, through its deliberative process, is best situated to sort out what one commentator has referred to as "[t]he schizophrenias of international criminal law". ${ }^{169}$ Given the gravity of the issues at stake and the lack of clarity on the many issues surrounding the development of this important and powerful modern jurisprudence, let's hope that Congress will heed the Supreme Court's call to action.

\footnotetext{
${ }^{169}$ S. R. Ratner, 'The Schizoprenias of International Criminal Law', 33 Texas International Law Journal (1998) p. 237.
} 